\title{
Nursing Course on Drug Addiction and its Effects on Beliefs and Intentions: A Quasi-experimental Study
}

Topic: Promotion and prevention.

Contribution to the discipline: The plans of study in Nursing not only influence the quality of patient care, but also promote the health of future professionals. This quasi-experimental research highlights the possible benefits to bachelor nursing students when they take a course aimed at promoting knowledge and skills for the care of drug-dependent patients. When comparing students who did not receive specific education on drug addiction with those who did, the results suggest that such training may have positive effects on a personal level, for example a decrease in the beliefs in favor of substance use and number of days they reported have used tobacco and marijuana.

\section{ABSTRACT}

Objective: To determine the impact of a course aimed at the care of persons with drug dependence on the beliefs and intentions of drug use among bachelor nursing students. Materials and methods: A quasi-experimental study conducted with a non-equivalent comparison group composed of 210 Mexican students of both sexes. Two Likert-type instruments were used to measure the beliefs and intentions of drug use, before and after a semester-long course. Results: At the end of the study, a significant interaction was found $(F=3.56, p=0.050, \eta 2 p=0.025)$, which suggests a greater decrease in beliefs in favor of drug use among students who took the course on drug addiction. Regarding drug use intentions, a general decrease was observed in the entire sample $(F=10.13, p=0.002$, $\eta 2 p=0.059$ ). Conclusions: Courses on the care of drug addiction can have beneficial effects on nursing students by modifying beliefs and intentions to carry out unhealthy behaviors such as the use of substances. These results demand to verify if the effects remain beyond the completion of university education.

\section{KEYWORDS (SOURCE: DeCS)}

Intention; nursing education research; health promotion; substance-related disorders; Mexico.

\section{DOI: 10.5294/aqui.2020.20.2.7}

Para citar este artículo / To reference this article / Para citar este artigo

Villegas-Pantoja MA, Méndez-Ruiz MD, De Valle-Alonso MJ, García-Perales LA. Nursing Course on Drug Addiction and its Effects on Beliefs and Intentions: A Quasiexperimental Study. Aquichan. 2020;20(2):e2027. DOI: https://doi.org/10.5294/aqui.2020.20.2.7

1 https://orcid.org/0000-0001-9917-8439. Universidad Autónoma de Tamaulipas, México.mapantoja@uat.edu.mx

$2 \bowtie$ https://orcid.org/0000-0002-4527-0296. Universidad Autónoma de Tamaulipas, México. mdmendez@docentes.uat.edu.mx

3 https://orcid.org/0000-0001-9792-0425. Universidad Autónoma de Tamaulipas, México. mjdevalle@docentes.uat.edu.mx

4 https://orcid.org/0000-0002-6424-0586. Universidad Autónoma de Tamaulipas, México. lagarcia@docentes.uat.edu.mx
Received: 04/03/2020

Sent to peers: $30 / 03 / 2020$

Approved by peers: $28 / 04 / 2020$

Accepted: 04/05/2020 


\section{Asignatura de Enfermería sobre drogodependencias y sus efectos sobre las creencias e intenciones: estudio cuasi experimental}

\section{RESUMEN}

Objetivo: determinar el impacto de una asignatura orientada al cuidado de usuarios drogodependientes sobre las creencias e intenciones del uso de drogas en estudiantes de la Licenciatura en Enfermería. Materiales y métodos: estudio cuasi experimental con un grupo de comparación no equivalente realizado en 210 estudiantes mexicanos de ambos sexos. Se utilizaron dos instrumentos tipo Likert para medir las creencias e intenciones del uso de drogas, antes y después de una asignatura con duración de un semestre. Resultados: al final del estudio, se encontró una interacción significativa $(F=3,56, p=0,050, \eta 2 p=0,025)$, que sugiere una mayor disminución de las creencias a favor de las drogas entre los estudiantes que cursaron la asignatura sobre drogodependencias. Respecto a las intenciones del uso de drogas, se apreció una disminución generalizada en toda la muestra ( $F=10,13, p=0,002, \eta 2 p=0,059)$. Conclusiones: las asignaturas sobre cuidados en las drogodependencias pueden tener efectos beneficiosos en los estudiantes de Enfermería al modificar las creencias y las intenciones de llevar a cabo conductas no saludables como el uso de sustancias. Los resultados demandan revisar si los efectos permanecen más allá de la finalización de los estudios universitarios.

PALABRAS CLAVE (FueNte: DeCS)

Intención; investigación en educación de enfermería; promoción de la salud; trastornos relacionados con sustancias; México. 


\section{Disciplina de toxicodependências no curso de Enfermagem e seus efeitos sobre crenças e intenções: estudo quase experimental}

\section{RESUMO}

Objetivo: determinar o impacto de uma disciplina orientada ao cuidado de pessoas toxicodependentes sobre as crenças e intenções do uso de drogas em estudantes de Enfermagem. Materiais e métodos: estudo quase experimental com um grupo de comparação não equivalente, realizado com 210 estudantes mexicanos de ambos os sexos. Foram utilizados dois instrumentos tipo Likert para medir as crenças e intenções do uso de drogas, antes e depois de terem aula da referida disciplina durante um semestre. Resultados: no final do estudo, verificou-se uma interação significativa $\left(F=3,56 ; p=0,050 ; h^{2} p=0,025\right)$ que sugere uma maior diminuição das crenças a favor das drogas nos estudantes da matéria sobre toxicodependência. Quanto às intenções do uso de drogas, constatou-se uma diminuição generalizada em toda a amostra $\left(F=10,13 ; p=0,002 ; h^{2} p=0,059\right)$. Conclusões: as disciplinas sobre cuidados de pessoas toxicodependentes podem ter efeitos benéficos nos estudantes de Enfermagem ao transformar as crenças e as intenções de realizar comportamentos não saudáveis como o uso de substâncias psicoativas. Contudo, os resultados exigem revisar se os efeitos permanecem após a finalização dos estudos universitários.

PALAVRAS-CHAVE (Fonte: DeCS)

Intenção; pesquisa em educação de enfermagem; promoção da saúde; transtornos relacionados ao uso de substâncias; México. 


\section{Introduction}

The use of psychoactive substances - both legal and illegal- represents unhealthy behavior that may have consequences for individual, family and social well-being (1-2). It is a growing problem, having become one of the leading causes of morbidity and mortality worldwide. In this regard, the United Nations Office on Drugs and Crime (2) points out in its most recent world report that nearly $35,000,000$ people suffer from a substance use disorder, and that in 2017 alone, there were 42,000,000 healthy years of life lost due to disability and 585,000 deaths directly related to drug use. This situation requires that nursing and related sciences professionals adopt actions aimed at its effective incorporation in the fight against addictions, through prevention, treatment, and rehabilitation activities.

In this connection, from the second half of the twentieth century, curriculum adjustments in the study plans were used as a strategy to promote the participation of nursing professionals in the care of drug-dependent people (3). International organizations (such as the Inter-American Drug Abuse Control Commission, through the Hemispheric Drug Strategy) (4) and national agencies have made curriculum adjustments to ensure that new graduates have specific knowledge and skills needed to provide effective care (5). This trend continues up to the present because of the persistent lack of training among nursing professionals (6). In the case of Mexico, the Mexican Federation of Associations of Faculties and Schools of Nursing (FEMAFEE) established some basic guidelines to improve the training of new generations, such as the inclusion of contents on addictions, by means of courses and the development and incorporation of specialization courses on nursing care for persons with drug dependence (7-8).

Evidence indicates that taking study programs with specific courses and contents may be a strategy to improve the skills of nursing professionals and the quality of care for drug users (9-11); however, its protective effects on the behavior of nursing students have been the subject of very little studies (5). For example, some studies in developed countries suggest that taking courses on drug addiction could improve nurses' negative attitudes related to the use of psychoactive substances (12-3). In addition, it has been documented that it could increase the perception of risk associated with drug addictions (14). In this regards, it is of particular interest to know if it could have effects on students' beliefs and intentions related to substances use, since they have a critical role in the motivational system, which explains the use of drugs (15).

It is stated that beliefs influence intentions and that intentions, in turn, may precede behaviors (16). This has been evaluated in studies on behaviors such as the use of addictive substances (15-16). In this respect, the literature suggests that when nursing professionals ignore the issue of drug addiction (for example, due to positive beliefs about drug use or because they are users of addictive substances), they are less inclined to care for drugdependent patients (17), and a worse performance as preventive agents is observed (18). This could contribute to the continuous increase in the number of cases of substance use among nursing professionals $(14,19)$. This is partly due to the characteristics of the profession and the stage of development in which they are in when pursuing their degree (the beginning of substances use usually occurs during the second decade of life, simultaneously with university education) $(18,20)$.

The lack of studies conducted with the population of Mexican nursing students is a knowledge gap, on which professors and health researchers should focus. Furthermore, the search for well-being of the drug-dependent people and nursing students are important reasons for evaluating whether the courses on nursing care for persons with drug dependence - recently incorporated into the curriculum - have any effect on the beliefs and intentions related to drug use. The region in which Tamaulipas is located, in Mexico, on the border with the United States of America, is characterized by having prevalences above the national average of consumption of licit and illicit substances (21). For this reason, it was decided to conduct a research that would allow us to answer the following question: What is the impact of taking a course on the care of persons with drug dependence on the beliefs and intentions of drug use in Mexican bachelor nursing students?

\section{Methodology}

Quasi-experimental study, in which a group of bachelor nursing students who took a course on the care for drug addiction was compared with a group that did not take this course (22). Measurements were performed at the beginning and end of the semester-long course. Sampling was considered non-probabilistic (all enrolled students were recruited). The final sample was 
stratified as follows: 120 students distributed in four classrooms that took the nursing course on the care for drug addiction (called Nursing for Addictions [Enfermería ante las Adicciones], taught to students under a new study program), and 90 students distributed in four control classrooms that did not take the course (although they received information on this subject in the Thesis Seminar course, which they took during that period, when they were under another study program). The study was conducted during the second half of 2018, while they were in the seventh semester. The sample size was sufficient to detect a medium effect size $(d=0.5)$, with an alpha error set at 0.05 and $94.0 \%$ power to perform comparative analyzes.

The plan of study of the Bachelor's degree in Nursing consists of 312 credits, with 7,648 hours in total, and is eight semesters long. The curriculum includes 63 courses divided into three cores: Basic training, professional practice training, and disciplinary trainining. The course on the care for persons with drug dependence corresponds to the disciplinary training core (that is, courses aimed at promoting nursing skills). It is divided into six units that address the following topics: Etiology, epidemiology, vulnerable groups, pharmacokinetics and pharmacodynamics, prevention, diagnosis and treatment, and nursing care.

The class was taught at a rate of four theoretical hours per week (4 credits of the System of Assignment and Transfer of Academic Credits [SATCA, by its Spanish abreviation]) by nursing professionals with postgraduate degree (master's or doctorate degree) and with experience in the care for drug addiction or in addiction research. The methodology included lectures delivered by professors, analysis of documents, discussion groups and presentation of real-life experiences. Among the didactic resources, the clinical cases, the practice of anamnesis and identification of risk factors in the population for convenience (such as individual assignments), the application of screening methods and the emergency care videos stand out. It should be noted that, because of the limited availability of specialized care centres where to practice the care of persons with drug dependence, compulsory hours of clinical practice have not been included. With respect to the comparison group, as part of this study, no specific training on addictions was provided during measurements. However, after the research (over the year of their social service), the comparison group received some speeches given by professors, on Saturdays, in order to complement their training in this area.

\section{Instruments}

A sociodemographic data sheet and two instruments were used to measure the study variables. The data sheet was composed of thirteen items grouped into two sections. The first section had questions designed to record sex, semester, age and experience in the care of drug-dependent patients. The second section included a table of prevalences of the use of licit (alcohol and tobacco) and illicit drugs (marijuana, cocaine, inhalants, heroin, and controlled drugs) in the last 30 days (that is, prevalence in the last month).

The first instrument was the Spanish version of the beliefs about substance abuse questionnaire (23). The instrument was used to find out young people's beliefs about the consumption of psychoactive substances. The seven-point Likert-type scale consists of 20 items, where 1 indicates Strongly disagree and 7 indicates Strongly agree. The score ranges from 20 to 140 points, where the higher the score, the stronger the beliefs in favor of drug use. This instrument has been reported to have acceptable reliability in the Mexican population $(\alpha=0.81)$.

The second instrument was the drug use intentions scale (24). This scale applies to people who do not consume addictive substances and who do not have the intention to consume any substance, as well as to those who have already consumed them and have the intention to consume them again. It was developed based on the theory of planned behavior, which states that intentions can be predicted by measuring three constructs: Attitude, subjective norm, and perceived behavioral control. Thus, its 64 items allow measuring these constructs. Attitude was indicated by the scores of the behavioral beliefs (13 items) and value attributed to beliefs (13 items) subscales; the subjective norm, by means of the scores of the normative beliefs (four items) and willingness to change (four items) subscales; and perceived behavioral control, through the consumption opportunities (15 items) and perceived behavioral control (15 items) subscales.

As a last step, a total intention score was calculated, composed of the subtotals of the three constructs (attitude, subjective norm, and perceived behavioral control). Therefore, the higher the score, the greater the intention to use drugs. This instrument has been reported to have sufficient level of global reliability $(\alpha=0.91)$ in the Mexican population, as well as its respective subscales. 


\section{Data collection procedures}

After approval of the study by the research ethics committees, the authorization of the management staff of the educational institution was requested. Subsequently, the group of researchers visited each classroom to invite students. Recruitment and initial measurement took place at the beginning of the academic period, just before students started classes. The interviewers were research assistants.

The objective of the study was explained verbally and a written informed consent form was provided. It was specified that those who did not wish to participate in the research were free to not answer the instruments, without their academic status in the institution being affected. The instruments were the data card, the belief scale and the drug use intentions scale. Their application in each corresponding classroom lasted approximately 25 minutes.

Six months later, just before the end of the academic period, the final measurement was performed, the classrooms (in some cases, laboratories or areas of clinical practice) were re-visited and the instruments were applied again. An alphanumeric code was used to match them between the initial and final measurements. Research development is observed in figure 1 . It is noteworthy that the general attrition was estimated at $22.38 \%$ ( $f=47$ ) between the two measurements, mainly because some participants could not be found $(18.09 \%, f=38)$ or because they refused to participate in the follow-up $(4.29 \%, f=9)$.

\section{Data analysis}

Descriptive analyzes consisted of measures of central tendency and dispersion, percentages and frequencies. The KolmogorovSmirnov test with Lilliefors correction was used, and it was found that the study variables did not present a normal distribution. Thus, it was decided to normalize the variables (in this case, by logarithmic transformation, as there was a right-skewed asymmetry). This enabled to perform the two-way ANOVA parametric test $(2 \times 2)$, where the time factor was the repeated measurement or intra-subject reliability measurement (initial measurement vs. final measurement), and the clustering factor was the inter-subject reliability measurement (students who took the course on the care for persons with drug dependence vs. comparison group).

Assumptions of sphericity (Mauchly's test with $p>0.05$ ), homocedasticity (Levene's test with $p>0.05$ ) and homogene-
Figure 1. CONSORT flow diagram on the development of the quasi-experimental study

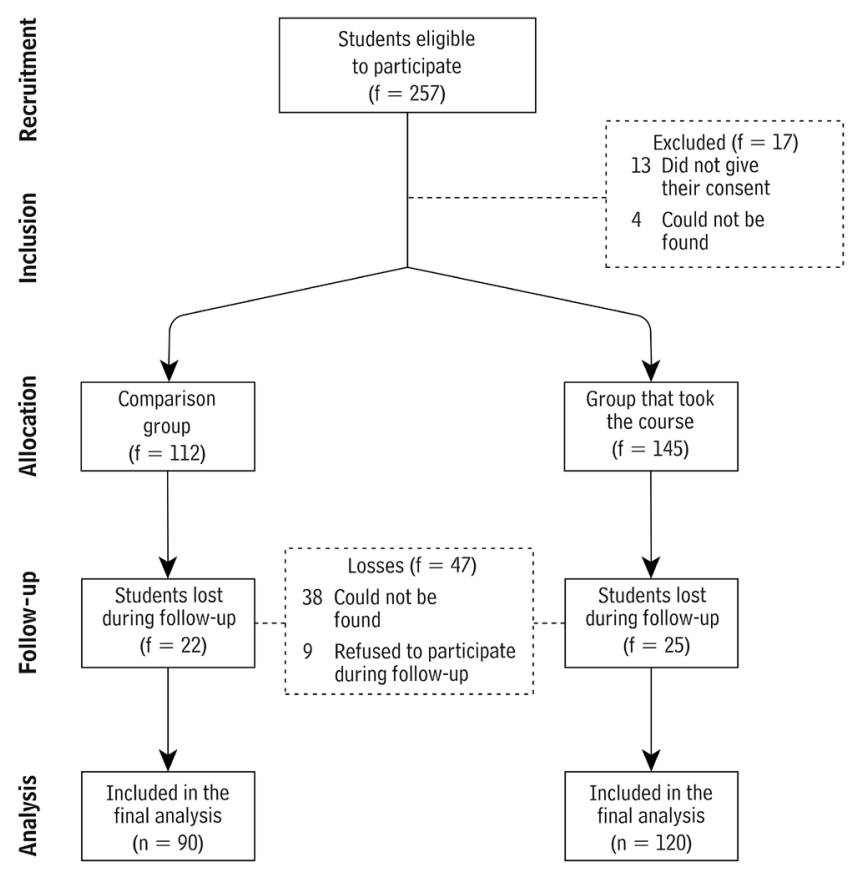

Source: Own elaboration.

ity of variance-covariance matrices (Box's M test with $p>0.05$ ) were verified. In all cases, the requirements were met and the F-statistic was interpreted (the higher the value, the greater the probability of occurring significant differences). In the case of non-parametric variables, the chi-square test ( $X^{2}$; to compare proportions between two independent groups) and the Wilcoxon test (to compare related groups) were used. Finally, the reliability of the instruments was evaluated by calculating the Cronbach's alpha coefficient. All analyzes were performed with the SPSS statistical package version 24.0 for Apple Macintosh.

\section{Ethical aspects}

The study was approved by the research ethics committees of the Faculty of Nursing (protocol CA-A017), Universidad Autónoma de Tamaulipas, Mexico. In addition, it complies with the guidelines of the General Health Law on Health Research in force in Mexico, which is also based on the general principles of the Declaration of Helsinki. 


\section{Results}

All instruments showed an acceptable reliability $(a>0.700)$, both in the initial and final measurements.

Table 1. Instruments reliability

\begin{tabular}{|c|c|c|c|c|}
\hline \multirow{2}{*}{\multicolumn{2}{|c|}{ Instruments }} & \multirow{2}{*}{ Items } & \multicolumn{2}{|c|}{$\begin{array}{c}\text { Reliability } \\
\text { (Cronbach's alpha) }\end{array}$} \\
\hline & & & $\begin{array}{c}\text { Initial } \\
\text { measurement }\end{array}$ & $\begin{array}{c}\text { Final } \\
\text { measurement }\end{array}$ \\
\hline \multicolumn{2}{|c|}{$\begin{array}{c}\text { Beliefs about substance abuse } \\
\text { questionnaire }\end{array}$} & 20 & 0.815 & 0.839 \\
\hline \multicolumn{2}{|c|}{ Drug use intentions scale } & 64 & 0.951 & 0.962 \\
\hline \multirow{2}{*}{$\begin{array}{l}\text { Attitude } \\
\text { subscale }\end{array}$} & Behavioral beliefs & 13 & 0.936 & 0.958 \\
\hline & $\begin{array}{l}\text { Value attributed } \\
\text { to beliefs }\end{array}$ & 13 & 0.922 & 0.934 \\
\hline \multirow{2}{*}{$\begin{array}{c}\text { Subjective } \\
\text { norm subscale }\end{array}$} & Normative beliefs & 4 & 0.805 & 0.859 \\
\hline & $\begin{array}{l}\text { Willingness to } \\
\text { change }\end{array}$ & 4 & 0.886 & 0.881 \\
\hline \multirow{2}{*}{$\begin{array}{c}\text { Perceived } \\
\text { behavioral } \\
\text { control } \\
\text { subscale }\end{array}$} & $\begin{array}{l}\text { Consumption } \\
\text { opportunities }\end{array}$ & 15 & 0.900 & 0.927 \\
\hline & $\begin{array}{c}\text { Perceived } \\
\text { behavioral control }\end{array}$ & 15 & 0.970 & 0.961 \\
\hline
\end{tabular}

Source: Own elaboration.

Although there was a greater representation of female students $(78.3 \%)$, participants from both curricula reported similar prevalences of the use of alcohol, tobacco, marijuana, and controlled drugs $(p>0.05)$. There were also no significant differences between the proportions of participants with previous experiences in the care of persons with drug dependence during their clinical practices in the previous semesters $(p>0.05)$ (table 2$)$.

The objective of this study was to identify changes in the beliefs and intentions of drug use among bachelor nursing students at the end of a course on the care of drug users. By means of the ANOVA test (Table 3), it was identified that in the case of beliefs about substance use, there was a significant main effect exerted by the time factor $(F=5.51, p=0.020, \eta 2 p=0.033)$, as a decrease in beliefs in favor of drugs was observed throughout the sample in the final measurement. However, an interaction between the time $x$ clustering factors $(F=3.56, p=0.050, \eta 2 p=0.025)$ was also found, which indicates that, over time, the changes in beliefs about drug use were different between the two groups of students (table 3). In figure 2 (subsection A), it can be corroborated that, at the end of the study, the participants who took the course reported a decrease in their beliefs in favor of drugs.
Table 2. Sociodemographic characteristics of participants in the initial measurement

\begin{tabular}{|c|c|c|c|c|c|}
\hline \multirow{2}{*}{ Variables } & \multicolumn{2}{|c|}{$\begin{array}{c}\text { Group that took the } \\
\text { course }\end{array}$} & \multicolumn{2}{|c|}{ Comparison group } & \multirow{2}{*}{ Chi-square test } \\
\hline & $f$ & $\%$ & $f$ & $\%$ & \\
\hline \multicolumn{6}{|c|}{ Sex } \\
\hline Men & 26 & 21.6 & 35 & 38.9 & \multirow{2}{*}{$\begin{array}{l}X^{2}=8.768 \\
p=0.012\end{array}$} \\
\hline Women & 94 & 78.3 & 55 & 61.1 & \\
\hline \multicolumn{6}{|c|}{ Previous experiences in the care of persons with drug dependence } \\
\hline Yes & 52 & 43.3 & 45 & 50.0 & \multirow{2}{*}{$\begin{array}{l}x^{2}=0.920 \\
p=0.402\end{array}$} \\
\hline No & 68 & 56.7 & 45 & 50.0 & \\
\hline \multicolumn{6}{|c|}{ Alcohol use (sometime in life) } \\
\hline Yes & 107 & 89.2 & 78 & 86.7 & \multirow{2}{*}{$\begin{array}{l}x^{2}=0.306 \\
p=0.668\end{array}$} \\
\hline No & 13 & 10.8 & 12 & 13.3 & \\
\hline \multicolumn{6}{|c|}{ Tobacco use (sometime in life) } \\
\hline Yes & 57 & 47.5 & 46 & 51.5 & \multirow{2}{*}{$\begin{array}{l}x^{2}=0.268 \\
p=0.676\end{array}$} \\
\hline No & 63 & 52.5 & 44 & 48.9 & \\
\hline \multicolumn{6}{|c|}{ Marijuana use (sometime in life) } \\
\hline Yes & 25 & 20.8 & 20 & 22.2 & \multirow{2}{*}{$\begin{array}{l}x^{2}=0.059 \\
p=0.866\end{array}$} \\
\hline No & 95 & 79.2 & 70 & 77.8 & \\
\hline \multicolumn{6}{|c|}{ Use of controlled drugs (sometime in life) } \\
\hline Yes & 11 & 9.2 & 9 & 10.0 & \multirow{2}{*}{$\begin{array}{l}x^{2}=0.041 \\
p=0.839\end{array}$} \\
\hline No & 109 & 90.8 & 81 & 90.0 & \\
\hline
\end{tabular}

Note: $f=$ frequencies; $\%=$ porcentages; $X^{2}=$ chi-square statistical test; $\mathrm{p}=$ statistical significance.

Source: Own elaboration.

Regarding drug use intentions, only a significant main effect exerted by the time factor was identified $(F=10.13, p=0.002$, $\eta 2 p=0.059$ ), as well as the absence of interaction between the time $x$ clustering factors or the absence of the main effect of the clustering factor (table 3). That is, at the end of the study, there was a general decrease in drug use intentions, but without differences between the students in both groups (Figure 1, subsection B).

Additionally, comparisons of the number of days (in the last month) of consumption of alcohol, tobacco, marijuana and controlled drugs were performed. Since these were variables with low response rate and strong asymmetry, the Wilcoxon non-parametric test was used. In the final measurement, the students who took the course showed a significantly lower number of days of tobacco use $(Z=-2.107, p=0.035)$, and there was a reduction in the number of days of marijuana use with a tendency to significance $(Z=-1.890, p=0.057$ ). It is worth mentioning that no statistically significant differences were identified among the students in the comparison group. 
Table 3. Changes in scores of beliefs and intentions of drug use among bachelor nursing students

\begin{tabular}{|c|c|c|c|c|c|c|c|c|}
\hline \multirow{3}{*}{ Indicators } & \multicolumn{2}{|c|}{ Group that took the course } & \multicolumn{2}{|c|}{ Comparison group } & \multirow{3}{*}{ Factors } & \multirow{3}{*}{$\mathbf{F}$} & \multirow{3}{*}{$\eta_{p}^{2}$} & \multirow{3}{*}{ p } \\
\hline & Initial measurement & Final measurement & Initial measurement & Final measurement & & & & \\
\hline & $M(S D)$ & $M(S D)$ & $M(S D)$ & $M(S D)$ & & & & \\
\hline $\begin{array}{l}\text { Beliefs about drug } \\
\text { use }\end{array}$ & $6.58(0.89)$ & $6.24(0.87)$ & $6.30(0.99)$ & $6.26(1.05)$ & $\begin{array}{c}\text { Time } \\
\text { Time } \times \text { clustering } \\
\text { Clustering }\end{array}$ & $\begin{array}{l}5.51 \\
3.56 \\
1.08 \\
\end{array}$ & $\begin{array}{l}0.033 \\
0.025 \\
0.007\end{array}$ & $\begin{array}{l}0.020 \\
0.050 \\
0.299\end{array}$ \\
\hline $\begin{array}{l}\text { Drug use } \\
\text { intentions }\end{array}$ & $3.38(0.31)$ & $3.33(0.30)$ & $3.37(0.29)$ & $3.31(0.30)$ & $\begin{array}{c}\text { Time } \\
\text { Time } \times \text { clustering } \\
\text { Clustering }\end{array}$ & $\begin{array}{c}10.13 \\
0.36 \\
0.29\end{array}$ & $\begin{array}{l}0.059 \\
0.002 \\
0.002\end{array}$ & $\begin{array}{l}0.002 \\
0.569 \\
0.589\end{array}$ \\
\hline
\end{tabular}

Note: $F=$ analysis of variance statistical test; $\eta^{2}=$ Partial eta squared;

$M=$ Mean; $S D=$ Standard deviation; $p=$ Statistical significance.

Source: Own elaboration.

Figure 2. Profile graphs of beliefs and intentions of drug use as a function of the time and clustering factors
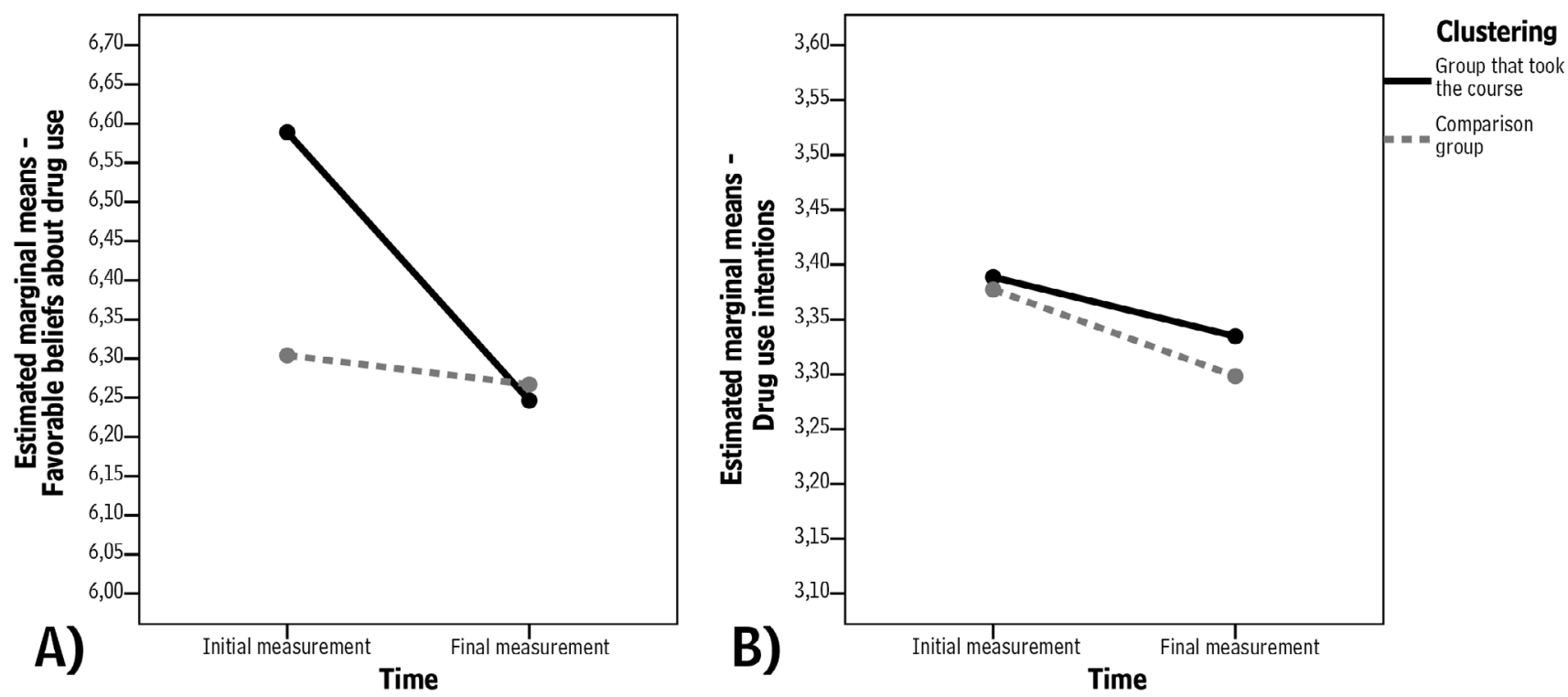

Source: Own elaboration.

\section{Discussion}

The present study identified that education on the nursing care of drug-dependent patients changed positive beliefs about drugs in bachelor nursing students. Thus, a decrease in positive beliefs among the students who took the course was registered in the final measurement. This suggests that the skills and knowledge acquired in the course could benefit students by modifying their personal beliefs about drugs.

It is possible that changes in beliefs are due, in part, to increased knowledge about the consequences of drug use, since 
Table 4. Comparison of the number of days of consumption of addictive substances in the last month between the initial and final measurements

\begin{tabular}{|c|c|c|c|c|c|c|}
\hline $\begin{array}{c}\text { Days of substances } \\
\text { use } \\
\text { in the last month }\end{array}$ & \multicolumn{2}{|c|}{$\begin{array}{c}\text { Initial } \\
\text { measurement }\end{array}$} & \multicolumn{2}{c|}{$\begin{array}{c}\text { Final } \\
\text { measurement }\end{array}$} & \multirow{2}{*}{ Wilcoxon test } \\
\cline { 2 - 5 } & M & SR & M & SR & \\
\hline Alcohol & 1.37 & 600.50 & 1.08 & 575.50 & $\begin{array}{c}\mathrm{Z}=-0.134 ; \\
\mathrm{p}=0.894\end{array}$ \\
\hline Tobacco & 2.37 & 191.00 & 1.00 & 62.00 & $\begin{array}{c}\mathrm{Z}=-2.107 ; \\
\mathrm{p}=0.035\end{array}$ \\
\hline Marijuana & 0.24 & 2.50 & 0.18 & 10.00 & $\begin{array}{c}\mathrm{Z}=-1.890 ; \\
\mathrm{p}=0.057\end{array}$ \\
\hline Controlled drugs & 0.64 & 0.00 & 0.29 & 0.00 & $\begin{array}{c}\mathrm{Z}=0.001 ; \\
\mathrm{p}=0.999\end{array}$ \\
\hline \multicolumn{2}{|c|}{ Participants in the comparison group } & \\
\hline Alcohol & 1.63 & 236.00 & 1.88 & 325.00 & $\begin{array}{c}\mathrm{Z}=-0.804 ; \\
\mathrm{p}=0.422\end{array}$ \\
\hline Tobacco & 1.70 & 40.00 & 1.95 & 113.00 & $\begin{array}{c}\mathrm{Z}=-1.743 ; \\
\mathrm{p}=0.091\end{array}$ \\
\hline Marijuana & 0.65 & 1.00 & 0.06 & 0.00 & $\begin{array}{c}\mathrm{Z}=-1.010 ; \\
\mathrm{p}=0.317\end{array}$ \\
\hline Controlled drugs & 0.44 & 0.00 & 0.86 & 3.00 & $\begin{array}{c}\mathrm{Z}=-1.342 ; \\
\mathrm{p}=0.180\end{array}$ \\
\hline
\end{tabular}

Note: $M=$ Mean; $S R=$ Sum of ranks; $Z=$ Wilcoxon statistical test. $p=$ Statistical significance.

Source: Own elaboration.

such information can contribute to the development of a more critical view of its benefits and a greater perception of risk (2526). In this sense, throughout the course, information is provided on the epidemiology of addiction, as well as the characteristics of vulnerable groups and the consequences of the abuse of different addictive substances. In addition to being informative, to approach these topics could have an impact by raising awareness of personal health, since it was also found that many students were users of addictive substances (for example, more than $20.0 \%$ had used marijuana sometime in life). In fact, the significant decrease in the number of days of tobacco and marijuana use among course participants is a contribution of this research, since no studies were found focused on detecting changes in the self-reported substance use in this population due to the curriculum adjustments. Instead, most of what has been reported in the literature was limited to describing changes in attitude, perception or skills (9-11, 13-14, 27-28).
On the other hand, the similarity in scores of drug use intentions between both groups could be because changes in the drug use intentions scale require changes in other antecedent elements. In this connection, they may be due to the planned manipulation of constructs such as the subjective norm, perceived behavioral control and attitudes -in addition to beliefs (16). Different interventions have focused on changing intentions through the constructs mentioned above and, in general, are characterized not only by providing educational information, but also by being based on activities that strengthen behavioral control (role-playing scenarios) (27), and considering social norms (for example, including the participation of important people who have an influence on participants) (29-30).

Although the course program does not meet these attributes, it would be possible to include some activities that aim to strengthen the subjective norm by handling with social pressure or through the establishment of group commitments, for example. It is worth mentioning that, although the scores of drug use intentions are not good, it has been reported that people do not necessarily act according to their intentions (16). In this way, the significant decrease in the number of days of tobacco and marijuana use found among the students who attended the nursing course on the care for drug addiction could be an indication of change in their behavior. However, it would be necessary to confirm whether the intentions change over an extended period or in a larger sample. It has been reported that interventions aimed at modifying the intentions of substance use usually show small effect sizes (30) and, therefore, they have more requirements to be met. In addition, it would also be useful to analyze whether the decrease in the number of days of substance use remains beyond the end of the academic period.

Among the limitations of this study, the control of information to which participants have access stands out. As this is a research conducted in a natural environment, participants continued their day-to-day activities, which may include acquiring information or skills that improve beliefs or intentions related to drug use. Although this bias can occur in both groups, it is not possible to identify if it occurs with greater intensity in any one in particular. In addition, the generalization of the results is limited due to the underrepresentation of male students, as there is evidence that men have a higher frequency and quantity of use of addictive substances (31-32) and their attitudes related to substances 
use differ from those of women (33). However, the low number of male participants did not allow further analysis without compromising the power of statistical tests. Finally, a last limitation was the non-obligatory nature of taking the nursing course on the care practices for drug addictions, since it is likely that the application of the skills acquired in class can contribute to changes in beliefs and intentions (ll).

\section{Conclusions}

Education and training in nursing care of drug-dependent patients — provided through specialized courses on this subject — can modify positive beliefs about drugs in bachelor nursing students. This indicates that, in addition to the acquisition of knowledge and skills frequently reported in the literature, taking the course could also have a positive impact on behavior, through the modification of personal beliefs about drugs. It is possible that the decrease in beliefs in favor of drugs will facilitate, in the future, the reduction of intentions or consumption of addictive substances in this population. However, it is still necessary that teachers and those responsible for curricular changes conduct follow-up studies to verify if the changes in beliefs remain in the medium term period.

\section{Acknowledgments}

We thank the different institutional authorities for their contribution to the improvement of educational processes through research, as well as the participants for their availability. Their collaboration was essential to the development of this manuscript.

Conflict of interests: None declared.

\section{References}

1. Organización Mundial de la Salud. Global status report on alcohol and health [Internet]. Ginebra: World Health Organization; 2018 [citado 2020 feb. 28]. Disponible en: https://apps.who.int/iris/bitstream/hand le/10665/274603/9789241565639-eng.pdf

2. Oficina de las Naciones Unidas Contra la Droga y el Delito. Informe Mundial sobre las Drogas 2019: resumen, conclusiones y consecuencias en materia de políticas [Internet]. 2019 [citado 2020 feb. 28]. Disponible en: https://wdr.unodc. org/wdr2019/prelaunch/WDR2019_B1_S.pdf

3. Finnell DS, Savage CL, Hansen BR, Sanchez M, White KM, Johnson JA, et al. Integrating substance use content in an "overcrowded" nursing curriculum. Nurse Educ [Internet]. 2017;43(3):128-31. DOI: https://doi.org/10.1097/ nne.0000000000000438

4. Wright MG, Lujan MJ. The ES/CICAD/OAS school of nursing Project: A model of excellence for professional and scientific development on drug related issues in Latin America. Text \& Context Nursing [Internet]. 2013;22(2):561-69. DOI: https://doi.org/10.1590/S0104-07072013000200035

5. García-Cardona M, Ramírez-Elías A. La educación de enfermería y las adicciones. Una revisión de literatura. Revista de Enfermería del Instituto Mexicano del Seguro Social [Internet], 2010;18(1):35-42. Disponible en: http://revistaenfermeria.imss.gob.mx/editorial/index.php/revista_enfermeria/article/view/406/424

6. Savage CL, Daniels J, Johnson JA, Kesten K, Finnell DS, Seale JP. (2017). The inclusion of substance use-related content in advanced practice registered nurse curricula. J Prof Nurs [Internet]. 2017;34(3):217-20. DOI: http://doi.org/10.1016/j. profnurs.2017.08.006

7. Esparza SE, Alonso MM, López KS, Rodríguez L. editores. Competencias específicas de enfermería en la reducción de la demanda de drogas. Monterrey: Tendencias; 2014.

8. Villegas-Pantoja MA, Mendez-Ruiz MD. Nursing and substance use disorders in Mexico. Nurs Sci Q [Internet]. 2016;29(2):163-66. DOI: http://doi.org/10.1177/0894318416630092 
9. Nash AJ, Marcus MT, Cron S, Scamp N, Truitt M, McKenna Z. Preparing nursing students to work with patients with alcohol or drug-related problems. J Addict Nurs [Internet]. 2017;28(3):124-30. DOI: https://doi.org/10.1097/ JAN.0000000000000175

10. Smothers Z, Reynolds V, McEachern M, Derouin AL, Carter BM, Muzyk A. Substance use education in schools of nursing: A systematic review of the literature. Nurse Educ [Internet]. 2018;43(3):136-39. DOI: http://doi.org/10.1097/ NNE.0000000000000449

11. Knopf-Amelung S, Gotham H, Kuofie A, Young P, Manney Stinson, R, Lynn J, Barker K, Hildreth J. Comparison of instructional methods for screening, brief intervention, and referral to treatment for substance use in nursing education. Nurse Educ [Internet]. 2018;43(3):123-27. DOI: https://doi.org/10.1097/NNE.0000000000000439

12. Bühler A, Schulze K, Rustler C, Scheifhacken S, Schweizer I, Bonse-Rohmann M. Tobacco prevention and reduction with nursing students: A non-randomized controlled feasibility study. Nurse Educ Today [Internet]. 2017;48:48-54. DOI: https://doi.org/10.1016/j.nedt.2016.09.008

13. Rassool GH, Rawaf S. Predictors of educational outcomes of undergraduate nursing students in alcohol and drug education. Nurse Educ Today [Internet]. 2008;28(6):691-701. DOI: https://doi.org/10.1016/j.nedt.2007.11.005

14. Stewart DM, Mueller CA. Substance use disorder among nurses. A curriculum improvement initiative. Nurse Educ [Internet]. 2018;43(3):132-35. DOI: http://dx.doi.org/10.1097/nne.0000000000000466

15. Bermúdez J, Contreras A. Predictores psicosociales del consumo de tabaco en adolescentes: extensiones de la teoría de la conducta planificada. Revista de Psicopatología y Psicología Clínica [Internet]. 2008;13(3):175-86. DOI: https://doi. org/10.5944/rppc.vol.13.num.3.2008.4058

16. Ajzen I, Dasgupta N. Explicit and implicit beliefs, attitudes, and intentions. The role of conscious and unconscious processes in human behavior. En: Haggard P, Eitam B, editores. The sense of agency. Nueva York: Oxford University Press; 2015. p. 115-44.

17. De Barros MA, Rassool GH, Dos Santos MA, Pillon SC. The impact of an educational program in brief interventions for alcohol problems on undergraduate nursing students. J Addict Nurs [Internet]. 2015;26(3):129-35. DOI: https://doi. org/10.1097/jan.0000000000000086

18. Garrido-González I, Bugarín-González R, Machín-Fernández AJ. Consumo de drogas en estudiantes de enfermería. Enfermería Clínica. 2015;26(3):174-80. DOI: https://doi.org/10.1016/j.enfcli.2015.11.006

19. Telumbre-Terrero JY, Esparza-Almanza SE, Alonso-Castillo BA, Alonso-Castillo MT. Actitudes hacia el consumo de alcohol y consumo de alcohol en estudiantes de enfermería. Investigación en enfermería: imagen y desarrollo [Internet]. 2017;19(2):69-81. DOI: http://dx.doi.org/10.11144/Javeriana.ie19-2.ahca

20. Kelly AB, Weier M, Hall WD. The age of onset of substance use disorders. En: De Girolamo G, McGorry P, Sartorius N, editores. Age of onset of mental disorders. Cham (Suiza): Springer; 2018. p. 149-67. DOI: https://doi.org/10.1007/9783-319-72619-9_8

21. Instituto Nacional de Psiquiatría Ramón de la Fuente Muñiz, Instituto Nacional de Salud Pública, Comisión Nacional Contra las Adicciones, Secretaría de Salud. Encuesta Nacional de Consumo de Drogas, Alcohol y Tabaco 2016-2017: reporte de drogas [Internet]. México: Gobierno de México; 2017 [citado 2020 feb. 28]. Disponible en: https://www. gob.mx/salud\%7Cconadic/acciones-y-programas/encuesta-nacional-de-consumo-de-drogas-alcohol-y-tabaco-encodat-2016-2017-136758

22. Polit FD, Beck CT. Investigación en enfermería. Fundamentos para el uso de la evidencia en la práctica de la enfermería. 9. ${ }^{\text {a }}$ ed. Barcelona: Wolters Kluwer; 2018.

23. Beck A, Wright F, Newman C, Liese B. Terapia cognitiva de las drogodependencias. Barcelona: Paidós; 1999.

24. Rodríguez-Kuri SE, Díaz-Negrete DB, Gracia-Gutiérrez de Velasco SE, Guerrero-Huesca JA, Gómez-Maqueo EL. Capacidad predictiva de la teoría de la conducta planificada en la intención y uso de drogas ilícitas entre estudiantes mexicanos. Salud Mental [Internet]. 2007;30(1):68-81. Disponible en: http://www.revistasaludmental.mx/index.php/salud_mental/article/view/1150/ 
25. Alhyas L, Al Ozaibi N, Elarabi H, El-Kashef A, Wanigaratne S, Almarzouqi A, et al. Adolescents' perception of substance use and factors influencing its use: A qualitative study in Abu Dhabi. JRSM Open. 2015;6(2):1-12. DOI: https://doi. org/10.1177/2054270414567167

26. Myers LB [Internet]. Changing smokers' risk perceptions-for better or worse? J Health Psychol [Internet]. 2014;19(3):32532. DOI: https://doi.org/10.1177/1359105312470154

27. Scudder AT, Bucey JC, Loughran MJ, Korach N, Strong G, Anderson J, et al. Screening, brief intervention, and referral to treatment (SBIRT) expansion of training to non-physician healthcare graduate students: Counseling psychology, nursing, occupational therapy, physical therapy, and physician assistant studies. Subst Abus [Internet]. 2019. 1-11. DOI: http://doi.org/10.1080/08897077.2019.1695705

28. Rabanales J, López A, Párraga I, Campos M, Simarro MJ, López-Torres J. Self-assessment of alcohol consumption as a health-education strategy in nursing students. Nurse Educ Today [Internet]. 2015;35(1):132-37. DOI: https://doi. org/10.1016/j.nedt.2014.08.004

29. Marsiglia FF, Ayers SL, Baldwin-White A, Booth J. Changing Latino adolescents' substance use norms and behaviors: The effects of synchronized youth and parent drug use prevention interventions. Prev Sci [Internet]. 2016;17(1):1-12. DOI: https://doi.org/10.1007/s11121-015-0574-7

30. Steinmetz H, Knappstein M, Ajzen I, Schmidt P, Kabst R. How effective are behavior change interventions based in the Theory of Planned Behavior? A three-level meta-analysis. Z Psychol [Internet]. 2016;224(3):216-33. DOI: http://doi. org/10.1027/2151-2604/a000255

31. Kulis SS, Marsiglia FF, Nuño-Gutiérrez BL, Lozano MD, Medina-Mora ME. Traditional gender roles and substance-use behaviors, attitudes, exposure, and resistance among early adolescents in large cities of Mexico. J Subst Use [Internet]. 2018;23(5):471-80. DOI: https://doi.org/10.1080/14659891.2017.1405088

32. Boulton MA, O'Connell KA. Past year substance use by student nurses. J Addict Nurs [Internet]. 2017;28(4):179-87. DOI: https://doi.org/10.1097/jan.0000000000000193

33. Feingold D. Attitudes towards substance use disorders among students in the social sciences: The role of gender and terminology. Subst Use Misuse [Internet]. 2020;55(3):519-532. DOI: https://doi.org/10.1080/10826084.2019.1683199 